\title{
Evaluasi Tentang Pengetahuan Kewirausahaan Dan Efikasi Diri Dalam Meningkatkan Intensi Berwirausaha (Studi Kasus Pada Mahasiswa Politeknik Negeri Bengkalis)
}

\author{
TRI HANDAYANI ${ }^{1}$, DWI ASTUTI ${ }^{2}$ \\ Jurusan Administrasi Niaga Politeknik Negeri Bengkalis \\ Email: trihandayani@polbeng.ac.id ${ }^{1}$
}

\begin{abstract}
This study aims to determine the level of entrepreneurial knowledge and self efficacy as well as its influence on the entrepreneurship intention in the students of Bengkalis State Polytechnic. This research uses quantitative approach with survey method which focuses on explanation of causal relationship between variables and hypothesis testing. Sampling using Taro Yamane or Slovin formula so that obtained sample of 82 people. The number of samples that have been obtained then determined the number of each sample by the number of students in each study program by proportionate random sampling. Sampling using probability sampling technique with random sampling method. Data will be collected through questionnaires distributed to respondents. Data analysis was done by descriptive and inferential technique with multiple linear regression analysis using SPSS program. The results showed that entrepreneurship knowledge has a positive and significant influence on the entrepreneurial intention of negliblical polytechnic students, Self Efficacy has no significant effect on Entrepreneurial Intention and also semantic testing shows that entrepreneurial knowledge and Self-efficacy have a positive and significant effect on Integrating entrepreneurship of polytechnic students of Bengkalis country. This research can be an evaluation that in giving entrepreneurship knowledge needs to be added elements or materials that lead to the provision of confidence and motivation so as to generate sense to students in entrepreneurship. Thus it can bring self-entrepreneurial self-efficacy that ultimately can affect the intention of students in entrepreneurship.
\end{abstract}

Keywords: Entrepreneurship Knowledge, Self Efficacy, Entrepreneurship Intention.

Saat ini Indonesia dihadapkan tingkat pengangguran yang tinggi yang merupakan masalah ekonomi makro yang harus segera diatasi. Pengangguran terjadi karena adanya kesenjangan antara penyedia lapangan kerja dengan jumlah tenaga kerja yang mencari pekerjaan. Selain itu pengangguran bisa terjadi meskipun jumlah kesempatan kerja tinggi akan tetapi terbatasnya informasi, perbedaan dasar keahlian yang tersedia dari yang dibutuhkan atau dengan dengan sengaja memilih utuk menganggur (pengangguran sukarela). Jika masalah makro ini tidak segera diatasi maka akan menyebabkan semakin meningkatnya tingkat kemiskinan di Indonesia (Laily dan Pristyadi, 2013).

Menurut Habibie (2009) dalam wardoyo (2012) jumlah penduduk Indonesia tahun 2015 diperkirakan 273 juta dan tahun 2045 sebanyak 364 juta jiwa.
Pada tahun 2045 diperkirakan penduduk miskin sekitar $10 \%$. Indonesia merupakan negara yang kaya akan Sumber Daya Alam (SDA) namun masih banyak penduduk yang miskin. Penanggulangan kemiskinan tidak dapat mengandalalkan SDA lagi karena jumlah pertumbuhan penduduk meningkat namun SDA semakin berkurang. Perlu dilakukan upaya transformasi dari mengandalkan SDA menjadi SDM secara berkesinambungan.

Upaya oleh pemerintah maupun swasta untuk menyediakan lapangan kerja tentulah tidak cukup untuk mengurangi pengangguran yang ada. Banyaknya jumlah lulusan baik SMA sederajat maupun lulusan Perguruan Tinggi lebih besar dibandingkan jumlah lapangan pekerjaan yang tersedia baik oleh pemerintah maupun perusahaan swasta. 
Menurut International Labor Organisation (ILO) (2013), tingkat pengangguran berdasarkan usia menunjukkan bahwa pengangguran terbesar berada pada usia 2024 tahun yaitu sebesar 29\%, kemudian diikuti usia 15-19 tahun sebesar 24\%, dan usia 25-29 tahun sebesar 16\%. Hal ini membuktikan bahwa angkatan kerja yang menganggur berapa pada usia yang sangat produktif. Hal ini terjadi karena mayoritas angkatan kerja masih dalam mindset mencari pekerjaan serta mengunjukkan bahwa minat berwirausaha pada masyarakat masih sangat rendah. Para siswa dan mahasiswa memiliki persepsi sebagai pencari kerja atau melamar pekerjaan setelah mereka lulus sekolah atau perguruan tinggi, bukan sebagai wirausaha yang menciptakan lapangan pekerjaan untuk orang lain. Hal ini terbukti dengan banyaknya lulusan yang berhasil menjadi karyawan dibandingkan memilih menjadi wirausahawan.

Kewirausahaan merupakan aspek yang sangat menunjang kemajuan perekonomian suatu daerah, karena dengan semakin banyaknya orang berwirausaha maka semakin banyaknya lapangan kerja dan secara otomatis terjadinya penyerapan tenaga kerja. Dengan hadirnya wirausaha seperti Usaha Mikro, Kecil dan Menengah (UMKM) akan menjadi salah satu konstribusi masyarakat dalam perkembangan dan kemajuan perekonomian daerah.

Bengkalis merupakan salah satu kecamatan dengan tingkat perkembangan yang sangat pesat dari aspek ekonomi, hal ini terlihat dari meningkatnya jumlah industri, perdagangan dan peningkatan kebutuhan jumlah komoditi yang ada di kecamatan bengkalis. Namun jika dibandingkan dengan daerah atau kota lain tingkat partisipasi Usaha Mikro Kecil Menengah (UMKM) sebagai pelengkap dalam kemajuan perokonomian Bengkalis masih sangat kecil.

Data Badan Pusat Statistik (BPS) Kabupaten Bengkalis tahun 2015 menunjukkan tingkat pengangguran tahun
2013 sebesar 7,02\% meningkat menjadi $7,30 \%$ di tahun 2014. Selain itu data BPS menunjukkan bahwa persentase penduduk kabupaten bengkalis yang memilih berusaha sendiri yaitu sebesar $37,95 \%$ dan sisanya adalah mereka yang memilih sebagai pekerja/ buruh/ karyawan serta sebagai pekerja bebas disektor pertanian dan non pertanian. Hal tersebut menunjukkan bahwa masih sedikit tingkat kepercayaan diri (efikasi diri) masyarakat bengkalis dalam berwirausaha. Mereka lebih memilih menjadi pekerja/ karyawan bahkan pekerja tidak dibayar (penganggur sukarela) dibandingkan dengan keinginan untuk berwirausaha membuka bisnis dan peluang kerja bagi orang lain. Hal ini merupakan fenomena yang perlu diperhatikan, bagaimana menciptakan kemandirian masyarakat dengan berwirausaha.

Salah satu program pemerintah dalam mendongkrak tingkat partisipasi masyarakat dalam kewirausahaan yaitu dengan mengedukasi kepada generasi muda tentang kewirausahaan, dalam hal ini dapat ditempuh melalui institusi pendidikan. Kurikulum pendidikan yang memuat mata kuliah kewirausahaan diharapkan dapat menjadi strategi dalam meningkatkan intensi berwirausaha pada masyarakat khususnya kepada mahasiswa. Hal ini sependapat dengan L. Saiman (2009). Beliau mengatakan bahwa Keberanian seseorang untuk mendirikan usaha sendiri (berwirausaha) sering kali terdorong oleh motivasi dari guru/ dosennya, atau koperasi yang memberikan mata pelajaran atau mata kuliah kewirausahaan yang praktis dan menarik, sehingga membangkitkan siswa/ mahasiswa untuk memulai berwirausaha. Zimmerer (2002) dalam Suharti dan Sirine (2011: 125), menyatakan bahwa salah satu faktor pendorong pertumbuhan kewirausahaan disuatu negara terletak pada peranan universitas melalui penyelenggaraan pendidikan kewirausahaan. Hal ini menunjukkan bahwa kemampuan kewirausahaan itu

$$
\text { p.ISSN: 2407-800X e.ISSN: 2541-4356 }
$$


dapat dipelajari melalui serangkaian pembelajaran pada pendidikan formal, serta dengan mengikuti pendidikan formal baik pada institusi pendidikan maupun sejumlah pendidikan dan latihan oleh lembaga tertentu dapat meningkatkan intensi (minat) berwirausaha.

Politeknik Negeri Bengkalis merupakan salah satu perguruan tinggi yang ada di kabupaten bengkalis, telah memberikan matakuliah kewirausahaan pada mahasiswanya. Selain itu juga Politeknik Negeri Bengkalis juga memiliki program yaitu Program Mahasiswa Wirausaha (PMW). Program ini memberikan bantuan dalam bentuk pendanaan dengan tingkat bunga $0 \%$ kepada mahasiwa yang ingin memulai berwirausaha. Diharapkan dengan adanya perkuliahan mata kuliah dan program mahasiswa wirausaha tersebut diharapkan dapat menjadi motivasi dan intensi mahasiswa dalam berwirausaha.

Walaupun demikian, pengetahuan kewirausahaan yang telah diperoleh sangat perlu didukung dengan kepercayaan diri seseorang dalam bertindak (efikasi diri). Apabila pengetahuan tidak didukung dengan efikasi diri yang baik dari setiap orang maka akan sulit memulai pengetahuan yang telah diperolehnya untuk dijadikan sebuah tindakan nyata yang dalam hal ini adalah keyakinan seseorang akan kemampuan diri untuk berwirausaha. Oleh sebab itu lingkungan pendidikan diharapkan juga dapat mencitapakan efikasi diri pada setiap siswa/ mahasiswa.

Penelitian terdahulu yang digunakan sebagai bahan rujukan dalam penelitian ini yaitu penelitian oleh Nurul Indarti dan Rokhima Rostiani (2008), yang melalukan penelitian tentang tingkat intensi mahasiswa dengan studi perbandingan mahasiswa Indonesia, Jepang dan Norwegia. Dalam penelitian ini meninjau dari sudut kebutuhan akan prestasi, efikasi diri dan kesiapan instrument yang mempengaruhi intensi mahasiswa dalam berwirausaha. Hasil penelitian menunjukkan tingkat intensi kewirausahaan Jurnal Daya Saing mahasiswa Indonesia signifikan lebih tinggi dibandingkan mahasiswa Jepang dan Norwegia, serta ditinjau dari efikasi diri sebagai salah satu faktor yang mempengaruhi intensi kewirausahaan tersebut, tingkat efikasi diri mahasiswa indonesia signifikan lebih tinggi dibandingkan mahasiswa Jepang dan Norwegia.

Penelitian lain yang menjadi rujukan adalah penelitian oleh Sarwono Nursito Arif dan Julianto Sri Nugroho (2013), dimana dalam penelitian ini membahas tentang seberapa Pengaruh Interaksi Pengetahuan Kewirausahaan Dan Efikasi Diri Terhadap Intensi Kewirausahaan mahasiswa Universitas Widya Dharma Klaten. Hasil penelitian menunjukkan bahwa pengetahuan kewirausahaan yang dibentuk melalui pendidikan kewirausahaan berpengaruh positif dan signifikan terhadap intensi kewirausahaan. Begitu juga efikasi diri yang merupakan faktor internal menunjukkan pengaruh yang signifikan terhadap intensi kewrausahaan.

Kewirausahaan (entrepreneurship) adalah kemampuan kreatif dan inovatif yang dijadikan dasar, kiat, dan sumber daya untuk mencari peluang menuju sukses. Inti dari kewirausahaan menurut Drucker (1959) adalah kemampuan untuk menciptakansuatu yang baru dan berbeda melalui pemikiran kreatif dan tindakan inovatif demi terciptanya peluang. (Suryana, 2009: 2)

Selanjutnya pengertian kewira usahaan menurut Instruksi Presiden RI No. 4 Tahun 1995, Kewirausahaan adalah semangat, sikap, perilaku dan kemampuan seseorang dalam menangani usaha dan atau kegiatan yang mengarah pada upaya mencari, menciptakan, menerapkan cara kerja, teknologi dan produk baru dengan meningkatkan efisiensi dalam rangka memberikan pelayanan yang lebih baik dan atau memperoleh keuntungan yang lebih besar.(Saiman, 2009: 43)

Dalam memulai suatu usaha
pengetahuan kewirausahaan

p.ISSN: $2407-800 X \quad$ e.ISSN: $2541-4356$ 
diperlukan, baik pengetahuan yang diperoleh secara formal maupun informal. Pendidikan diyakini dapat mengembangkan berbagai potensi yang dimiliki manusia. Dengan pendidikan, kekuatan intelektual, daya moral maupun daya sosial dapat dikembangkan. Selain itu melalui pendidikan pula, pengetahuan, sikap dan keterampilan dapat ditingkatkan. Pendidikan merupakan suatu usaha yang dilakukan secara sadar, yang bertujuan untuk mengubah tingkah laku seseorang. Kegiatan pendidikan tersebut perlu dirancang, diatur, dimonitor sedemikian rupa dan dievaluasi agar mampu mencapai tujuan yang telah ditentukan (Nursito dan Nugroho, 2013:151).

Menurut Suryana (2009: 4) seorang wirausaha tidak akan berhasil apabila tidak memiliki pengetahuan, kemampuan dan kemauan. Ada kemauan tetapi tidak memiliki kemampuan dan pengetahuan tidak akan membuat seseorang menjadi wirausaha yang sukses. Sebaliknya, memiliki pengetahuan dan kemampuan tetapi tidak disertai kemauan tidak akan membuat wirausaha mencapai kesuksesan.

Menurut Nursito dan Nugroho (2013:154) pengetahuan kewirausahaan didefinisikan sebagai tingkat pengetahuan sebagai hasil belajar setelah mengikut proses pendidikan kewirausahaan yangdiperlukan untuk memulai dan menjalankan usaha.

Selanjutnya, Suryana (2009: 4) menjelaskan bahwa terdapat beberapa pengetahuan yang harus dimiliki wirausaha adalah: (1) pengetahuan mengenai usaha yang akan dimasuki/ dirintis dan lingkungan usaha yang ada, pengetahuan tentang peran dan tanggung jawab, dan (3) pengetahuan manajemen dan organisasi bisnis.

Istilah efikasi diri (Self Efficacy) pertama kali dikemukakan oleh Albert bandura (1977). Menurut Nursito dan Nugroho (2013: 152) Definisi klasik untuk konsep efikasi diri adalah kemampuan seseorang atas kemampuan dirinya untuk meyelesaikan suatu pekerjaan (Bandura,
1977). Dalam perkembangan selanjutnya, Bandura dan Wood (1989), mendefinisikan efikasi diri sebagai keyakinan terhadap kemampuan seseorang untuk menggerakkan motivasi, sumber kognitif, dan serangkain tindakan yang diperlukan untuk memenuhi tuntutan situasi.

Menurut Indarti (2008) Efikasi diri adalah kepercayaan seseorang atas kemampuan dirinya untuk menyelesaikan suatu pekerjaan. Kondisi motivasi seseorang yang lebih didasarkan pada apa yang mereka percaya daripada apa yang secara objektif benar. Persepsi pribadi seperti ini memegang peranan penting dalam pengembangan intensi seseorang. (Daulay dan Ramadini,2012:2).

Bandura (1977) dalam wulandari (2010: 4) menjelaskan bahwa efikasi diri terdiri dari beberapa dimensi atau indikator. Masing-masing mempunyai implikasi penting didalam performansi, yang secara lebih jelas dapat diuraikan sebagai berikut:

\section{Magnitude (Tingkat Kesulitan)}

Magnitude adalah kemampuan seseorang untuk menyelesaikan tugas yang tingkat kesulitannya berbeda. Efikasi diri dapat ditunjukkan dengan tingkat yang dibebankan pada individu terhadap tantangan dengan tingkat yang berbeda dalam rangka menuju keberhasilan. Individu akan mencoba tingkah laku yang dirasa mampu dilakukannya dan akan menghindari tingkah laku yang dirasa di luar batas kemampuan yang dirasakannya

\section{Strength (Kekuatan)}

Strength berkaitan dengan kekuatan pada keyakinan individu atas kemampuannya. Individu mempunyai keyakinan yang kuat dan ketekunan dalam usaha yang akan dicapai meskipun terdapat kesulitan dan rintangan. Dengan efikasi diri, kekuatan untuk usaha yang lebih besar mampu didapat. Semakin kuat perasaan efikasi diri dan semakin besar ketekunan, maka semakin tinggi

p.ISSN: 2407-800X e.ISSN: 2541-4356 
kemungkinan kegiatan yang dipilih dan dilakukan dengan berhasil.

3. Generality (Generalitas)

Generality berkaitan dengan tingkah

laku dimana individu merasa yakin terhadap kemampuannya. Individu dapat merasa yakin terhadap kemampuan dirinya tergantung pada pemahaman kemampuan dirinya yang terbatas pada suatu aktivitas dan situasi tertentu atau pada serangkaian aktivitas dan situasi yang lebih luas dan bervariasi.

Menurut Elliot et al, (2003) dalam Nursito dan Nurgroho (2013:151) intensi adalah kecenderungan seseorang untuk memilih untuk melakukan atau tidak melakukan suatu pekerjaan. Teori ini memposisikan intensi sebagai penentu utama dari sebuah perilaku dan merupakan aspek psikologis yang berpengaruh terhadap perilaku atau tindakan seseorang.

Sehubungan dengan hal tersebut intensi seseorang terhadap sesuatu/ suatu pekerjaan akan berbeda-beda, karena hal ini disebabkan faktor pembentuk perilaku dari setiap orang yang berbeda-beda antara satu sama lain. Menurut Fishbein dan Ajzen (1975) dalam Nursito dan Nurgroho (2013:151) Intensi seseorang terhadap perilaku dibentuk oleh dua faktor utama yaitu sikap perilaku tertentu dan norma subjektif. Sikap merupakan evaluasi atau penilaian positif atau negatif seseorang terhadap sejumlah keyakinan terhadap objek tertentu. Sedangkan norma subjektif yaitu sejauh mana keinginan individu memenuhi harapan dari sejumlah pihak yang dianggap penting berkaitan dengan perilaku tertentu.

Berdasarkan pembahasan tentang pengertian intensi tersebut dapat disimpulkan bahwa intensi kewirausahaan adalah kecenderungan seseorang terhadap niat dan minat berwirausaha yang mengarah kepada perilaku untuk berwirausaha. Menurut Wardoyo (2012:3) Intensi berwirausaha adalah Tendensi keinginan individu melakukan tindakan wirausaha dengan menciptakan produk baru melalui peluang bisnis dan pengambilan risiko. Selanjutnya menurut menurut Katz dan Gartner (1988) dalam Indarti dan Rostiani (2008:4). Intensi kewirausahaan dapat diartikan sebagai proses pencarian informasi yang dapat digunakan untuk mencapai tujuan pembentukan suatu usaha. Intensi kewirausahaan adalah keadaan berfikir yang secara langsung dan mengarahkan perilaku individu ke arah pengembangan dan implementasi konsep bisnis yang baru (Nursito dan Nurgroho, 2013:151)

Indarti dan Rostiani (2008:4) menjelaskan bahwa Seseorang dengan intensi untuk memulai usaha akan memiliki kesiapan dan kemajuan yang lebih baik dalam usaha yang dijalankan dibandingkan seseorang tanpa intensi untuk memulai usaha. Seperti yang dinyatakan oleh Krueger dan Carsrud (1993), intensi telah terbukti menjadi prediktor yang terbaik bagi perilaku kewirausahaan. Oleh karena itu, intensi dapat dijadikan sebagai pendekatan dasar yang masuk akal untuk memahami siapasiapa yang akan menjadi wirausaha (Choo dan Wong, 2006).

Kemauan yang kuat untuk berkarya memberikan pengaruh yang positif terhadap kepuasan berwirausaha, oleh karenanya perlu adanya usaha untuk mendorong kemauan (Fatkhurahman, 2016).

\section{METODE}

Pendekatan penelitian yang digunakan dalam penelitian ini adalah pendekatan kuantitatif dengan metode survei. Populasi dalam penelitian ini seluruh mahasiswa Politeknik Negeri Bengkalis pada semester akhir karena dengan asumsi bahwa mahasiswa semester akhir (semester 6) sudah mendapatkan mata kuliah kewirausahaan, hal ini menjadi salah satu sumber pembentuk pengetahuan kewirausahaan yang merupakan salah satu variabel penelitian ini. Jumlah mahasiwa pada semester akhir (genap) tahun ajaran 2015/2016 adalah berjumlah 456 mahasiswa.

p.ISSN: $2407-800 X \quad$ e.ISSN: $2541-4356$ 
Pengambilan sampel menggunakan rumus Taro Yamane atau Slovin (Akdon, 2008: 44), maka diperoleh sampel sebanyak 82 sampel. Setelah diperoleh sampel pada masing-masing program studi, kemudian penarikan sampel dengan menggunakan metode sampel acak (random sampling) yaitu cara pengambilan sambel dari anggota populasi dengan menggunakan acak tanpa memperhatikan strata (tingkatan) dalam anggota populasi tersebut (Akdon, 2008: 41).

Analisis deskriptif dengan pendekatan statistik dan untuk mengetahui variabel yang mempengaruhi Intensi berwirausaha digunakan dengan analisi regresi linier berganda. Analisis ini memprediksikan nilai dari variabel dependen apabila variabel independen mengalami kenaikan atau penurunan dan untuk mengetahui arah hubungan antara variabel independen dengan variabel dependen.

\section{HASIL}

a. Analisi Regresi Linear berganda

Berdasarkan hasil analisi regresi linear berganda dengan SPSS, maka diperoleh hasil sebagai berikut:

Tabel 9. Hasil Regresi Linear Berganda

\begin{tabular}{|c|c|c|c|c|c|}
\hline Model & Unstandardia & Coefficients & $\begin{array}{l}\text { Standantized } \\
\text { Coefficients }\end{array}$ & 1 & Sig. \\
\hline 1 (Constant) & B & Std, Emor & Beta & $t$ & Sig. \\
\hline 1 (Coestant) & 1.778 & 1932 & & 920 & .360 \\
\hline $\begin{array}{l}\text { Pengettionan } \\
\text { Kenirmsahism }\end{array}$ & .269 & .062 & .443 & 4.352 & .000 \\
\hline Eun Efiksi Diri & .155 & .079 & .199 & 1.950 & 055 \\
\hline
\end{tabular}

Hasil regresi linear berganda yang ditunjukkan pada tabel 9 diperoleh persamaan regresinya berikut ini:

$$
Y=1.778+0,269 X_{1}+0,155 X_{2}
$$

Persamaan regresi diatas menjelaskan bahwa konstanta sebesar 1,778 menunjukkan jika pengetahuan kewirausahaan $\left(X_{1}\right)$ dan efikasi diri $\left(\mathrm{X}_{2}\right)$ adalah 0 (nol), maka nilai intensi kewirausahaan (Y) sebesar 1,778. Koefisien regresi variabel pengetahuan kewirausahaan $\left(\mathrm{X}_{1}\right)$ sebesar 0,269 menunjukkan jika pengetahuan kewirausahaan ditingkatkan sebesar 1 satuan, maka intensi kewirausahaan mahasiswa akan mengalami peningkatan sebesar 0,269 satuan, dengan demikian terdapat hubungan yang positif yaitu semakin ditingkatkan pengetahuan kewirausahaan kepada mahasiswa maka akan semakin meningkatkan intensi kewirausahaan mahasiwa. Koefisien regresi variabel efikasi diri $\left(\mathrm{X}_{2}\right)$ sebesar 0,155 menunjukkan bahwa jika efikasi diri ditingkatkan sebesar 1 satuan maka intensi kewirausahaan mahasiswa akan meningkat sebesar 0,155 satuan, dengan kata lain bahwa terjadi hubungan yang positif antara efikasi diri terhadap intensi kewirausahaan mahasiswa.

\section{b. Analisis Korelasi Ganda (R) dan Determinasi $\left(\mathrm{R}^{2}\right)$}

Analisis Korelasi ganda digunakanuntuk mengetahui seberapa besar hubungan yang terjadi antara variabel pengetahuan kewirausahaan $\left(\mathrm{X}_{1}\right)$ dan variabel efikasi diri $\left(\mathrm{X}_{2}\right)$ secara serentak terhadap variabel intensi kewirausahaan (Y). Nilai R berkisar antara 0 sampai 1 . Menurut Sugiyono (2012) pedoman untuk memberikan interpretasi koefisien korelasi adalah sebagai berikut:

$$
\begin{array}{ll}
0,00-0,199 & =\text { sangat rendah } \\
0.20-0.399 & =\text { rendah } \\
0,40-0,599 & =\text { sedang } \\
0,60-0,799 & =\text { kuat } \\
0,80-1,000 & \text { = sangat kuat }
\end{array}
$$

Hasil korelasi ganda dalam penelitian ini dapat dilihat pada tabel 10 berikut:

Tabel 10. Korelasi dan Determinasi

\begin{tabular}{|c|c|c|c|c|}
\hline Model & $\mathrm{R}$ & $\mathrm{R}$ Square & $\begin{array}{c}\text { Adjusted R } \\
\text { Square }\end{array}$ & $\begin{array}{c}\text { Std. Error of the } \\
\text { Estimate }\end{array}$ \\
\hline 1 & $552^{2}$ & 304 & 287 & 1.803 \\
\hline
\end{tabular}

Berdasarkan hasil yang diperoleh nilai korelasi (R) sebesar 0,552. Maka dapat disimpulkan bahwa terjadi hubungan yang sedang antara pengetahuan kewirausahaan

p.ISSN: $2407-800 X \quad$ e.ISSN: $2541-4356$ 
dan efikasi diri terhadap intensi kewirausahaan.

Dari tabel 10 dapat juga diperoleh hasil uji determinasi. Analisis determinasi digunakan untuk mengetahui seberapa besar prosentase sumbangan pengaruh variabel independen yaitu variabel pengetahuan kewirausahaan dan efikasi diri secara serentak terhadap variabel dependen yaitu variabel intensi kewirausahaan. Berdasarkan hasil yang telah diperoleh determinasi $\left(\mathrm{R}^{2}\right)$ yang ditunjukkan dengan nilai $\mathrm{R}$ Square adalah sebesar 0,304 atau 30,4\%. Hal ini menjelaskan bahwa prosentase sumbangan pengaruh kedua variabel indepenend dalam penelitian ini (pengetahuan kewirausahaan dan efikasi diri) sebesar 30,4\%. Sedangkan selebihnya $69,6 \%$ dipengaruhi oleh variabel lain yang tidak dibahas dalam penelitian ini.

\section{c. Uji Koefisien Regresi Parsial (Uji t)}

Uji ini digunakan untuk mengetahui apakah variabel pengetahuan kewirausahaan $\left(\mathrm{X}_{1}\right)$ dan efikasi diri $\left(\mathrm{X}_{2}\right)$ secara parsial berpengaruh signifikan terhadap variabel intensi kewirausahaan (Y). Hal ini sekaligus menjawab hipotesis 1 dan $2(\mathrm{H} 1$ dan $\mathrm{H} 2)$ dalam penelitian ini.

1. Pengujian pengaruh pengetahuan kewirausahaan terhadap intensi kewirausahaan.

Dari tabel 9 diperoleh $t_{\text {hitung }}$ variabel pengetahuan kewirausahaan sebesar 4.352 dengan perolehan tingkat signifikansi sebesar 0,000 . Hal ini menunjukkan nilai sig. 0,000 berada dibawah nilai probabilitas signifikansi $0,05(0,000<0,05)$, maka HO ditolak dan $\mathrm{H} 1$ diterima, ini berarti pengetahuan kewirausahaan berpengaruh positif dan signifikan terhadap intensi kewirausahaan mahasiswa politeknik negeri bengkalis.

2. Pengujian pengaruh efikasi diri terhadap intensi kewirausahaan

Berdasarkan tabel 9 diperoleh nilai $t_{\text {hitung }}$ variabel efikasi diri sebesar 1.950 nilai signifikansi (sig.) sebesar 0,055. Hal ini menunjukkan nilai sig. 0,055 diatas probabilitas signifikansi $0,05(0,055>$
0,05), maka $\mathrm{HO}$ diterima dan $\mathrm{H} 2$ ditolak, ini berarti efikasi diri tidak berpengaruh signifikan terhadap intensi kewirausahaan mahasiswa politeknik negeri bengkalis.

\section{d. Uji Koefisien Regresi Secara Simultan (Uji F)}

Uji $\mathrm{F}$ digunakan untuk mengetahui pengaruh secara simultan kedua variabel independen dalam penelitian ini terhadap variabel dependen. Uji ini sekaligus menjawab Hipotesis 3 (H3), Hasil uji F dapat dilihat pada tabel berikut:

Tabel 11. Korelasi dan Determinasi

\begin{tabular}{|c|c|c|c|c|c|}
\hline Nodel & Sum of Sulares & If & Mean Squart & $\mathrm{F}$ & Sig. \\
\hline 1 Rezession & 112.291 & $?$ & $56: 146$ & 17.20 & $60^{\circ}$ \\
\hline Rosital & 256.831 & 79 & 3.251 & & \\
\hline Total & 36.12 & 81. & & & \\
\hline
\end{tabular}

Berdasarkan tabel 11 diketahui nilai $F_{\text {hitung }}$ sebesar 17,270 dengan tingkat signifikansi (sig.) 0,000 . Hal ini menunjukkan bahwa nilai perolehan sig. Berada dibawah nilai probabilitas signifikansi $(0,000<0,005)$, maka $\mathrm{HO}$ ditolak dan $\mathrm{H} 3$ diterima. Selain itu juga pembuktian dapat dilakukan dengan membandingkan nilai $F_{\text {hitung }}$ dan $F_{\text {tabel }} . F_{\text {tabel }}$ diperoleh dengan melihat tabel $\mathrm{F}$,dengan $\mathrm{df}$ 1 (jumlah variabel-1 atau 3-1 = 2), dan df2 (n-k-1 atau 82-2-1=79), maka Perolehan $F_{\text {tabel }}$ adalah sebesar 3,112. Hal ini berarti $\mathrm{F}_{\text {hitung }}>\mathrm{F}_{\text {tabel }}$, maka $\mathrm{HO}$ ditolak dan $\mathrm{H} 3$ diterima, yang berarti pengetahuan kewirausahaan dan efikasi diri secara simultan berpengaruh positif dan signifikan terhadap intensi kewirausahaan.

\section{PEMBAHASAN}

pustaka serta bahasan dari seluruh laporan tugas akhir ini, berikut kesimpulan dari proyek akhir yang disusun oleh penulis tentang rancangan strategi pemasaran usaha kerupuk multisari yaitu: Analisa strategi pemasaran usaha Kerupuk Multisari merupakan hal pertama yang harus 
dilakukan untuk mengetahui strategi pemasaran yang telah digunakan ditinjau dari STP (Segmentting, Targetting dan Posisioning), segmentasi pasar yang difokuskan oleh usaha Kerupuk Multisari adalah segmentasi pasar demografis karena produk Kerupuk Multisari ini disukai oleh semua jenis usia, gender, pendapatan dan kelas sosial. Target pasar yang difokuskan oleh usah Kerupuk Multisari adalah target pasar demografis karena tingkat permintaan dari semua usia, jenis kelamin, semua pendapatan dan kelas sosial. Posisi pasar yang difokuskan oleh usaha Kerupuk Multisari adalah menjadi usaha Kerupuk Multisari yang memproduksi kerupuk dengan rasa terasi, kemudian usaha yang dilakukan untuk menarik perhatian konsumen adalah dengan mengikuti pameran makanan khas.

Strategi produk yang dilakukan pada proyek akhir untuk produk adalah mendesain ulang label dengan menambah daftar harga kerupuk dan beberapa slogan pada label produk, memperbaruhi label produk yakni mencetak label dalam bentuk stiker yang ditempatkan diluar kemasan produk, menambah pemasaran kemasan produk yang sebelumnya usaha Kerupuk Multisari hanya memasarkan satu bentuk kemasan produk, sehingga ditambah dengan kemasan produk yang lebih kecil atau yang lebih ekonomis, selain itu juga menambah variasi dari Kerupuk Multisari dengan memasarkan kerupuk dalam bentuk siap saji. Strategi penetapan harga yang dilakukan adalah menetapkan harga produk yang baru berdasarkan metode penetapan harga penetration princing yakni penetapan harga yang serendah-rendahnya. Strategi tempat pemasaran yang dipilih penulis adalah lokasi yang strategis dengan pangsa pasar yang banyak, dimana selama melaksanakan proyektelah didapat sebanyak 75 lokasi distribusi yang bersedia menjadi pengecer dengan menggunakan 2 jenis saluran distribusi (o-tingkat dan 1-tingkat). Strategi promosi yang dikembangkan adalah promosi melaui iklan seperti BBM, SMS dan facebook, baleho dan expo selain itu penulis juga melakukan promosi penjualan dan Jurnal Daya Saing personal selling dan penjualan langsung kepada konsumen.

Berdasarkan hasil pengujian hipotesis diketahui bahwa Pengetahuan kewirausahaan $\left(\mathrm{X}_{1}\right)$ berpengaruh positif dan signifikan terhadap intensi kewirausahaan (Y) mahasiswa politeknik negeri bengkalis. Hal ini menunjukkan bahwa pemberian pemahaman dan pengetahuan tentang kewirausahaan kepada mahasiswa akan meningkatkan wawasan yang mengarah kepada kegiatan kewirausahaan sehingga menimbulkan keinginan untuk terjun dibidang wirausaha. Hal ini mendukung penelitian sebelumnya oleh Arif dan Nugroho (2013) dimana secara umum menjelaskan terdapat pengaruh peningkatan pengetahuan kewirausahaan terhadap minat berwirausaha.

Hasil penelitian ini juga dapat menjadi evaluasi bahwa pemberian pemahaman dan pengetahuan tentang kewirausahaan kepada mahasiswa dapat terus ditingkatkan dengan berbagai metode dan motivasi belajar yang menarik minat mahasiswa untuk mempelajari kewirausahaan.

Hasil pengujian hipotesis menunjukkan bahwa efikasi diri $\left(\mathrm{X}_{2}\right)$ tidak berpengaruh signifikan terhadap intensi kewirausahaan (Y) pada mahasiswa politeknik negeri bengkalis. Hal tersebut berbeda dengan penelitian sebelum yaitu oleh Arif dan Nugroho (2013) serta penelitian oleh Indarti dan (2008) yang inti penelitian mereka menjelaskan terdapat pengaruh efikasi diri dalam menumbuhkan minat/ intensi berwirausaha. Disamping itu juga hasil rekapitulasi responden juga menunjukkan tingkat efikasi diri yang tinggi terhadap mahasiswa politeknik negeri bengkalis. Efikasi diri merupakan keyakinan seseorang atas kemampuan dirinya dalam suatu tindakan atau pekerjaan. Hal ini dapat ditarik kesimpulan bahwa tingkat efikasi mahasiswa dari aspek kewirausahaan masih perlu ditingkatkan. Keyakinan akan dirinya mampu untuk berbisnis dan berwirausaha perlu diasah lagi serta perlu mendapat motivasi untuk

p.ISSN: 2407-800X e.ISSN: 2541-4356 
meningkatkan keyakininan dirinya bahwa mereka mampu berwirausaha, berbisnis serta sukses sebagai wirausahawan.

Berdasarkan hasil pengujian hipotesis menunjukkan bahwa pengetahuan kewirausahaan $\left(\mathrm{X}_{1}\right)$ dan Efikasi diri $\left(\mathrm{X}_{2}\right)$ secara simultan berpengaruh positif dan signifikan terhadap Intesi kewirausahaan (Y) mahasiswa politeknik negeri bengkalis. Hal dapat ditarik kesimpulan bahwa pengetahuan kewirausahaan yang baik serta didukung dengan efikasi diri yang kuat tentang aspek kewirausahaan akan meningkatkan minat atau intensi mahasiswa dalam berwirausaha. Penelitian ini dapat menjadi evaluasi bahwa dalam pemberian pengetahuan kewirausahaan perlu ditambah unsur atau materi yang mengarah pemberian keyakinan dan motivasi sehingga menimbulkan sense kepada mahasiswa dalam berwirausaha. Dengan demikian dapat memunculkan efikasi diri kewirausahaan mahasiswa yang pada akhirnya dapat mempengaruhi intensi mahasiswa dalam berwirausaha.

\section{SIMPULAN}

Kesimpulannya dalam penelitian ini adalah pengetahuan kewirausahaan (Entrepreneurship Knowledge), berpengaruh positif dan signifikan terhadap Intensi kewirausahaan (Entrepreneurial Intention) mahasiswa politeknik negeribengkalis, Efikasi diri (Self Efficacy) tidak berpengaruh signifikan terhadap terhadap Intensi kewirausahaan (Entrepreneurial Intention) serta pengujian secara semultan menunjukkan bahwa Pengetahuan kewirausahaan dan Efikasi diri berpengaruh positif dan signifikan terhadap Intensi kewirausahaan mahasiswa politeknik negeri bengkalis. Penelitian ini dapat menjadi evaluasi bahwa dalam pemberian pengetahuan kewirausahaan perlu ditambah unsur atau materi yang mengarah pemberian keyakinan dan motivasi sehingga menimbulkan sense kepada mahasiswa dalam berwirausaha. Dengan demikian dapat memunculkan efikasi diri kewirausahaan mahasiswa yang pada akhirnya dapat mempengaruhi intensi mahasiswa dalam berwirausaha.

\section{DAFTAR RUJUKAN}

Akdon.2008. Cara menggunakan dan Memaknai Analisis Jalur (Path Analysis). Alfabeta. Bandung.

Arikunto, Suharsimi. 2010. Prosedur Penelitian Suatu Pendekatan Praktik. Rineka Cipta. Jakarta.

Badan Pusat Statistik. 2016. Statistik Daerah Kabupaten Bengkalis 2015. Badan Pusat Statistik Kabupaten Bengkalis. Bengkalis

Daulay,Rina Wahyuni \& Ramadini, Frida. 2013. Efikasi Diri Dan Motivasi Terhadap Keberhasilan Usaha, Jurnal Media Informasi Manajemen, Vol. 1 No. 4. Universitas SumateraUtara. Medan.

Fatkhurahman, F. (2016). Kepuasan Berwirusaha Melalui Kemauan Untuk Berkarya Usaha Industri Kecil. JEBI (Jurnal Ekonomi dan Bisnis Islam), 1(2), 143-153.

Indarti,Nurul \& Rostiani, Rokhima.2008. Intensi Kewirausahaan Mahasiswa: Studi Perbandingan antara Indonesia, Jepang dan Norwegia. Jurnal Ekonomika dan Bisnis Indonesia, Vol. 23, No. 4, Oktober 2008

International labour Organization.2013. Tren ketenagakerjaan dan sosial di Indonesia 2013: Memperkuat peran pekerjaan layak dalam kesetaraan pertumbuhan. 2013. Kantor Perburuhan Internasional/ Kantor ILO untuk Indonesia. Jakarta.

Kasmir, 2006, Kewirausahaan, PT. Raja Grafindo Persada, Jakarta.

p.ISSN: 2407-800X e.ISSN: 2541-4356 
Laily,Nur \& Prristyadi,Budiyono.2013. Teori Ekonomi, Edisi Pertama. Graha Ilmu. Yogyakarta.

Nursito,Sarwono \&Nugroho, Arif Julianto Sri. 2013. Analisis Pengaruh Interaksi Pengetahuan Kewirausahaan dan Efikasi Diri terhadap Intensi Kewirausahaan. Jurnal Kiat Bisnis Volume 5 No.2 Juni 2013. Universitas Widya Dharma Klaten.

Priyatno,Duwi.2010. Paham Annalisa Statistik Data dengan SPSS. Media Kom. Yogyakarta.

Rahayu, Puji Suci. 2009. Pengaruh Orientasi Kewrausahaan, Dinamika Lingkungan, Kemampuan Manajemen serta Strategi Bisnis Terhadap Kinerja (Studi Kasus pada Industri UKM Bordir di Jawa Timur). Dian Prima Lestari, Jawa Timur.

Saiman, Leonardius. 2009. Kewirausahaan: Teori, Praktik, dan Kasus-kasus. Salemba Empat. Jakarta.

Suharti,Lieli \& Sirine,Hani. 2011. FaktorFaktor yang Berpengaruh Terhadap Niat Kewirausahaan (Entrepreneurial Intention),(Studi Terhadap Mahasiswa Universitas Kristen Satya Wacana, Salatiga).

Sugiyono. 2012. Statistika Untuk Penelitian. Bandung. Alfabeta.

\section{. 2013. Metode Penelitian Kuantitatif, Kualitatif dan R\&D. Alfabeta. Bandung}

Suryana. 2009. Kewirausahaan, Pedoman Praktis: Kiat dan Proses Menuju Sukses. Edisi 3. Salemba Empat. Jakarta.
Wardoyo.2012. Pengaruh Pendidikan Dan Karakteristik Kewirausahaan Terhadap Intensi Berwirausaha Mahasiswa Pada Perguruan Tinggi Swasta Di Jakarta. Seminar Nasional Kewirausahaan dan Inovasi Bisnis II 2012 (SNKIB II 2012) Universitas Tarumanagara. Jakarta, 18 September 2012

Wulandari,Suci. 2010. Pengaruh Efikasi Diri Terhadap Minat Berwirausaha pada Siswa Kelas XII di SMK Negeri 1 Surabaya.

Available at: http://ejournal.unesa.ac.id/data/jou rnals/54/articles/1902/public/19023494-1PB.pdf 